\title{
Heritage Outreach, Fossils, Dinosaurs and Sites: How Locals' Perception Changes After 10 Years of Actions in Historic Urban Villages (Cuenca, Spain)
}

\author{
Lara de la Cita ${ }^{1}$ (1) $\cdot$ Mercedes Llandres ${ }^{2}$ (D) Ángela D. Buscalioni ${ }^{1}$ (i)
}

Received: 23 October 2020 / Accepted: 26 April 2021 / Published online: 9 June 2021

(c) The Author(s) 2021

\begin{abstract}
Cuenca, a small city with a rich historical and palaeontological heritage, is the ideal location to explore how the scientific knowledge of its inhabitants has changed over the years. In 2010 and 2019, two surveys were conducted on the streets of Cuenca to characterise their scientific profiles and how they perceive heritage outreach initiatives in palaeontology (i.e. visits and non-formal education in museums, research dissemination and mass media). For the present study, 320 responses were analysed through multivariate techniques (multiple correspondence analysis or MCA), using simple binary states and multiple nominal states. The results showed a significant disparity in the age demographic category: on the one hand, young people ( $<18$ years old) retained more scientific information linked to educational activities than older people in 2010; on the other hand, older Cuenca natives ( $>55$ and 35-55 years old) were the most informed and influenced by outreach and media in 2019, some of them even forming a particular group of palaeontology and dinosaur enthusiasts, herein named 'paleo-geeks'. In general, it was found that the majority of answers were congruent within the same year and corresponded with the sociocultural changes that Cuenca had experienced, from a rural to a more urban and diverse culture. Lastly, it was concluded that heritage outreach initiatives do influence the scientific profiles of Cuenca's inhabitants.
\end{abstract}

Keywords Education $\cdot$ Science museum $\cdot$ Scientific survey $\cdot$ Social palaeontology $\cdot$ Paleo-geeks

\section{Introduction}

What is the impact of scientific outreach in a small city (< 200,000 inhabitants) with limited economic resources but a rich cultural, geological and palaeontological heritage? This sociocultural model is quite common throughout the European Union, with many sites sharing these demographic, economic and patrimonial conditions, such as Dino Parque Lourinhã (Portugal), Site Paléontologique d'Angeac-Charente (France) or Ente Geopaleontologico di Pietraroja (Italy). The selected area for this study was the locality of Cuenca, situated in the central east of Spain (see Online Resource 1). The city

Lara de la Cita

lara.delacita@gmail.com

1 Biology Department, Faculty of Science and Centre for the Integration in Paleobiology (CIPB), Universidad Autónoma de Madrid, 28049 Madrid, Spain

2 MUPA, Museo Paleontológico de Castilla - La Mancha, Calle del Río Gritos, 5, 16004 Cuenca, Spain of Cuenca has a historical environment made up of ancient monuments tightly linked to natural spaces, as specified in the Vienna Memorandum for a Historic Urban Landscape (UNESCO 2005). These landscapes exert an influence on both inhabitants and visitors and in all the city activities that are carried out to foster better heritage values (Layuno 2007). The asserted claim was that having a variety of patrimony elements in localities like Cuenca has a positive influence when it comes to incorporating science into the lives of the citizens. This has an impact not only on their knowledge but also on their personal experiences, emotions and identity building (Le Goff 1998; Cuenca and Domínguez 2005). Although small, Cuenca has ten museums: six of them are devoted to Art, two to Religious culture and two to Science. The scientific museums, Museo de las Ciencias de Castilla-La Mancha (MCCM) and Museo Paleontológico (MUPA), were inaugurated in 1999 and 2015, respectively. The financial, educational and outreach resources that have been put into Cuenca to develop scientific culture (Fig. 1) are in consonance with the discovery of Early and Late Cretaceous sites with significant dinosaurs: Las Hoyas (129 Ma), discovered in 1985 (Poyato-Ariza and 
Fig. 1 Cultural context of Cuenca (Spain); a schema of the agents studied influencing the scientific profiles; b percentage of people who visited a museum (2010 and 2019) in Spain and Castilla-La Mancha, which is the autonomic government that includes Cuenca; c comparison of the culture expenditure (units: thousands of euros) in Castilla-La Mancha with the State Administration according data from National Institute of Statistics of Spain. The main events related to this study are indicated at the bottom of the graph
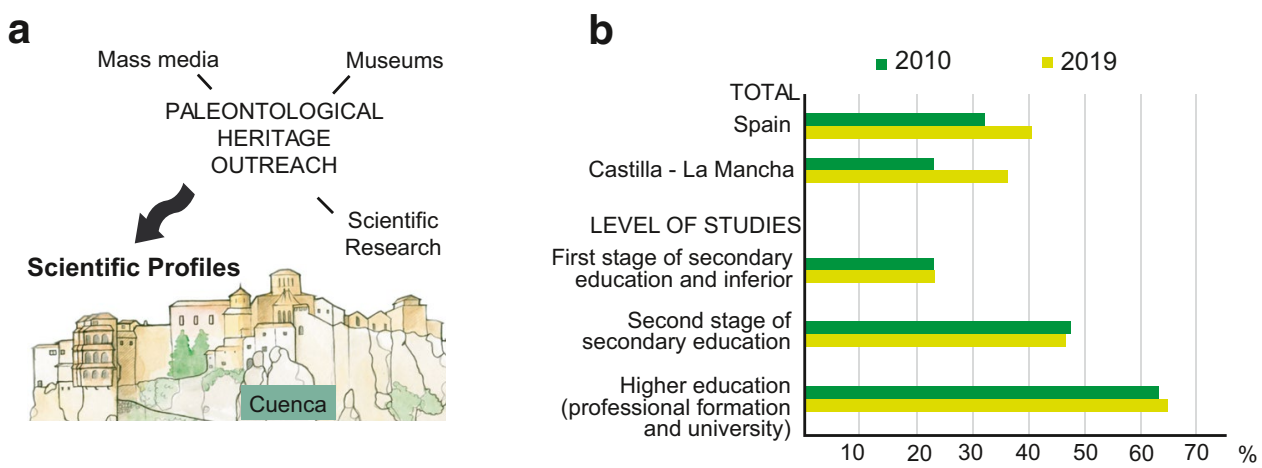

C

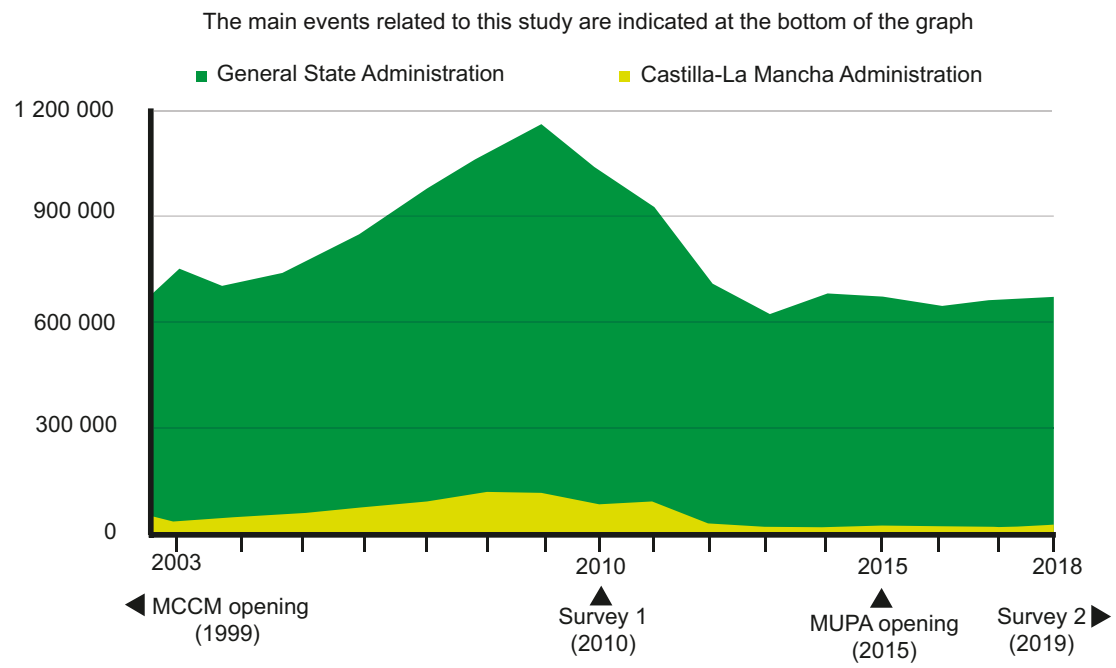

Buscalioni 2016), and Lo Hueco (70 Ma), in 2007 (Ortega et al 2008).

The main goal of this study was to evaluate the scientific profile of Cuenca's inhabitants by analysing two surveys performed over an interval of 10 years (2010-2019), to see how citizens improved in their motivations and palaeontological knowledge. The factors that were measured included the scientific understanding and the interest in science considering the proximity of museums, fossiliferous localities and the frequent scientific outreach and coverage of mass media (Fig. 1a, b) -all while assessing which values (social, scientific or patrimonial) interest citizens more. With dinosaurs being the most popular palaeontological topic throughout the world, this study discusses key features of the popularisation of the dinosaurs and lists some of the most frequent palaeontological misunderstandings.

\section{Heritage Outreach: Fossils, Dinosaurs and Sites}

Palaeontological heritage includes movable natural objects (fossils) and immovable ones (fossiliferous sites) (Guerrero-Arenas et al. 2020; Salamanca et al. 2018). This study contextualises the palaeontological heritage outreach actions that have been implemented by science museums, palaeontological research teams and the regional government. In what follows, the principal milestones reached in Cuenca will be mentioned, outlining the efforts and commitments made over 10 years.

The two science museums in Cuenca constantly develop informal and formal activities. The number of visitors to the MCCM was 55,589 in 2010, of whom 4400 were pupils from school groups. The number of visitors to the MUPA was 78,700 in 2019, of whom 8000 were pupils. Both museums have developed educational activities, MCCM since 2012 and MUPA since its creation in 2015, related to Earth Sciences, Palaeontology and, recently, a limited selection devoted to Evolution. Both museums (MCCM 2019; MUPA 2019) have displays and offer guided tours with instructors to explain the scientific context and fossils being exhibited. Both museums organise visits for school groups, and the information provided by the instructors is delivered according to the official school syllabus. The instructors also adapt their discourse when they interact with families, using a simpler narrative. In a similar vein, instructors replicate the colloquial practices palaeontologists develop when a precious fossil is 
discovered, introducing it with a nickname (see the MUPA blog, mupaclm.es/blog-2/). Also, the media have increased the usage of nicknames to popularise fossils (Allmon et al. 2012). Other activities are offered only on special days (Science Week, European Researchers' Night and Women's Day). Occasionally, associations visit the palaeontological locality of Las Hoyas guided by museum workers, but this activity is out of the normal school collaboration programme.

The palaeontological research teams at the Universidad Autónoma de Madrid (UAM) and the Universidad Nacional a Distancia (UNED) have promoted Cuenca's natural and palaeontological heritage through outreach programmes and non-formal education activities for years (http://www.uam. es/UAM/Las_Hoyas; http://godzillin.blogspot.com/), mostly on dinosaurs (Narváez and Alfaro 2019; https://extension. uned.es/actividad/idactividad/23528). Researchers have also studied the potential of fossil sites in the field of formal education, with higher education students participating in practical lectures about excavation campaigns and receiving expert palaeontological talks in museums. It is expected that these actions will encourage the training and professionalisation of future palaeontologists (Martín-Abad et al. 2017). Furthermore, researchers working at the Las Hoyas site have organised every year, since 2013, an open day where they show people the site and their work with the fossils.

Finally, as for the regional government, it has promoted nature trails with rural exhibition centres (Rutas de los Dinosaurios de Cuenca) (see Fig. 1c for trend in cultural investment). It has also developed the cultural website 'Portal de Cultura de Castilla-La Mancha', in which an entire section about Las Hoyas locality, created in May 2019, its fossil preservation characteristics and biodiversity is featured (de la Cita and Buscalioni 2019; Sanz et al. 2015). This website has produced a sensational increase in the number of Google searches for this fossil site within the Spanish community.

For a cursory exploration on the general impact that palaeontological heritage outreach has had in Cuenca, an Internet search aimed at Spanish and English websites was effectuated, tracking the keywords fossils, mammals, dinosaurs and, the fossil locality being examined in this study, Las Hoyas. Las Hoyas was discovered in the 1980s, and it is now famous worldwide. To explore its outreach impact, an analysis was made of how the search trends for 'Las Hoyas + dinosaur', 'Las Hoyas + fossils', 'Las Hoyas + mammal' and Las Hoyas itself have fluctuated since 2010 (Fig. 2). When assessing the mass media coverage of outreach initiatives at Las Hoyas (museums, research and regional government), it was found that, since 2010, outreach impact has fluctuated when it comes to Internet searches by Spanish users. However, the international Google searches showed a more constant and increasing trend. Interestingly, it was observed that the locality of Las Hoyas is progressively gaining relevance.

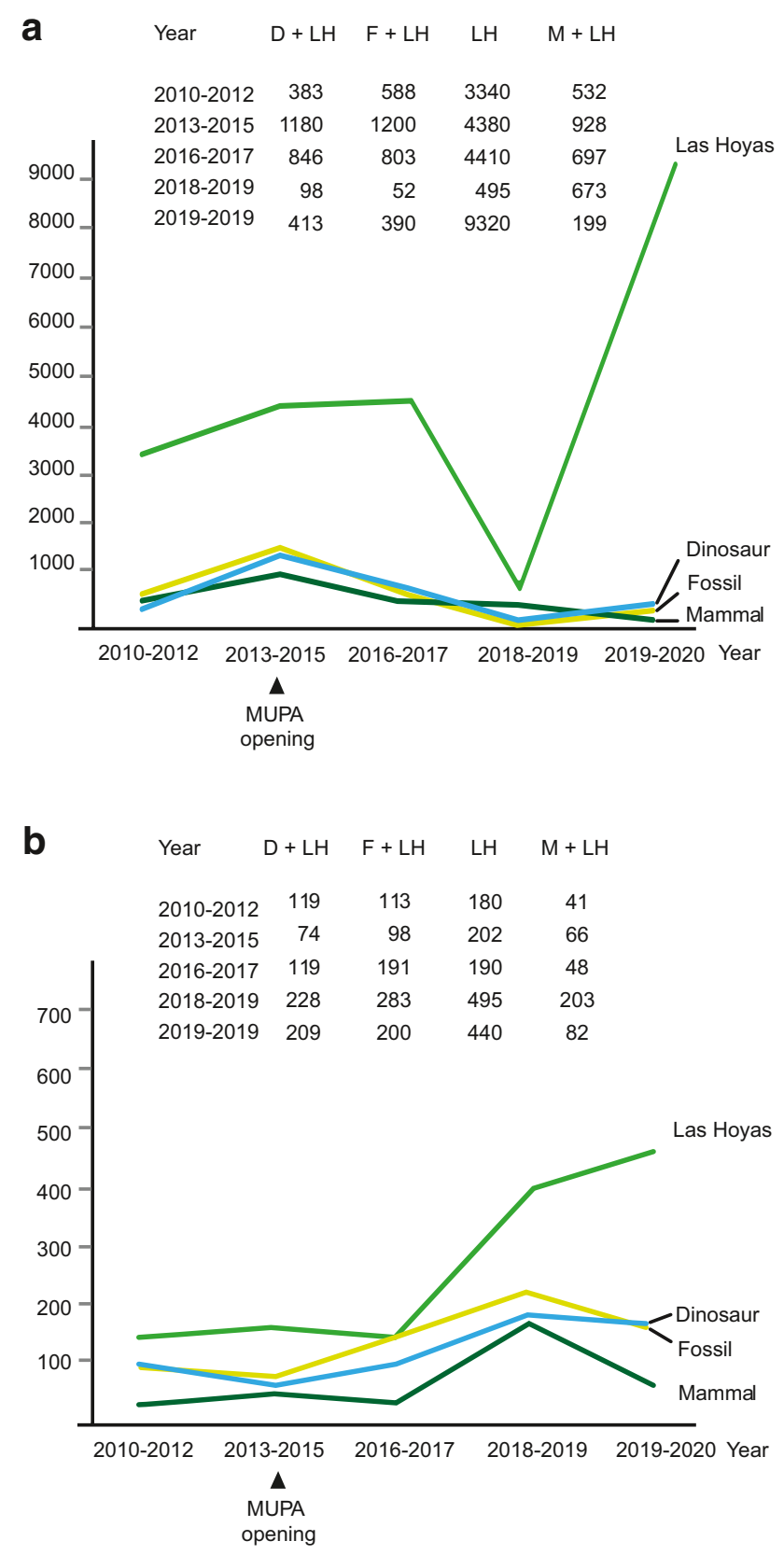

Fig. 2 Number of Google searches about Las Hoyas fossil site; a in Spanish (upper); b in English (bottom). The lines correspond to the values of tables inset: Las Hoyas (LH), Dinosaurs + Las Hoyas $(\mathrm{D}+\mathrm{LH})$, Fossil + Las Hoyas $(\mathrm{F}+\mathrm{LH})$ and Mammal + Las Hoyas $(\mathrm{M}$ $+\mathrm{LH})$

\section{Material and Methods}

\section{Study Area and Sample}

Cuenca is full of heritage, to such a point that it is popularly considered as the Spanish city with most culture per capita (Hermoso 2020). In this cultural context, palaeontology has developed in recent years, from occupying a small section 
in the Science Museum of Castilla-La Mancha to having its own museum (for more insights, see Online Resource 1). Therefore, Cuenca is like an open-air museum, where it is possible to measure to what extent science, and more precisely palaeontology, has become another element of the identity of Cuenca's inhabitants regarding their heritage. For this purpose, both surveys were executed entirely on the street, with the objective of measuring public perception and knowledge of heritage and palaeontology in a nonbiased environment-although the underage age group was partially surveyed in schools in 2019.

The population of the province of Cuenca has notably decreased from 217,716 inhabitants in 2010 to 193,329 in 2019 , and from 56,189 inhabitants in the city of Cuenca in 2010 to 54,690 in 2019 . The evaluation of the scientific profile of Cuenca's inhabitants was accomplished by analysing two surveys carried out over an interval of 10 years (2010 and 2019). Both surveys were implemented between July and September with the same sample size $(N=159)$. This size fitted the calculations (with a margin of error of $7 \%$ and a 92\% confidence level) using the Central Limit Theorem (Hibberts et al. 2012) based on the city of Cuenca's population size. To have an equal representation of all demographic groups (i.e. sex, age and birthplace in Table 1), a similar number of men and women $(89 \mathrm{M} / 70 \mathrm{~W})$ and people from the four pre-set age groups (<18: 40/18-35: 41/35-55: 40/ $>55: 38$ ) made up the 2010 survey. This was not as precise in 2019 though $(75 \mathrm{M} / 84 \mathrm{~W} ;<18: 42 / 18-35: 35 / 35-55$ : 49/> 55: 33).

\section{The Survey: Design, Objectives and Categorisation}

Design The survey was short and simple (see Online Resource 2 to see the survey models). It consisted of 11 questions in 2010 and 13 questions in 2019 (Table 1). The 2010 survey only included the MCCM. The MUPA was inaugurated in 2015 and now holds the palaeontological exhibition that was once in the MCCM. Therefore, in 2019, two more questions were added related to the MUPA: one Yes/No question and one open question. The first three demographic questions were used to classify the sample into different groups (sex, age and birthplace) and to measure whether there were significant differences among them and with respect to subsequent answers. The questions that followed (Table 1) measured general cultural knowledge, scientific interest and curiosity for palaeontology. Four of these questions integrated a Yes/No format, and the other three were open questions (that is, respondents could give an answer as detailed as they wanted without pre-set options). These questions were designed to progressively measure how much the respondents knew about heritage. Firstly, they explored people's general knowledge of museums in Cuenca; then, their knowledge of science museums; and ultimately, their knowledge of palaeontological heritage (both museums and sites). Finally, the last question offered three pre-given options, allowing respondents to give more than one answer and to propose options outside the set. This question gathered evaluative responses on what activitiesin the citizen's opinion-could improve palaeontological heritage outreach. The level of education and the professional occupation of the respondents were not included in the definition of the public profile.

Objectives The scientific profile analysed in this study is a representation of the scientific knowledge Cuenca's inhabitants have about their city. This profile was characterised by statistically noting the links between what people remembered or had experienced in relation to fossils, primarily in museums (Table 1, and Figs. 3, 4, 5, and 6). Through statistical analyses (bivariate and multivariate), the cases (individuals) were defined and catalogued into the aforementioned demographic categories, taking into account the variables relating to the interest that citizens bear or recall regarding scientific heritage. The expectation was that the results would make it possible to sort groups or profiles into categories defined by the combination of variable states.

By using the two samples separately (2010 and 2019), the aim was to provide a dynamic view on how the scientific interest of the citizens has changed over time. Since the survey combined Yes/No questions and open questions (in which the respondent could list scientific properties and species names), it was expected that a progression in the sample would be found, from a more general scientific profile (see general MCA in the "Statistical Method") to a more specific one (see detailed MCA in the "Statistical Method"). In the specific profile, the direct responses related to fossil names and localities were incorporated into the analysis. The way respondents named fossils and localities was categorised into different groups (see below) in order to rate their scientific interest. The contribution of each categorised response in the multivariate statistic provided a first layer to discuss the different emotions and expectations of Cuenca's citizens. Also, we documented the non-significant trends by exploring how frequently the different terms and names given appeared in the open questions.

Aiming to explore how heritage outreach strategies may have influenced the scientific knowledge of Cuenca's inhabitants, we will discuss the results obtained in the framework of the different heritage outreach scenarios (i.e. formal and non-formal education in museums, regional administration and scientific research; Fig. 7). Since Cuenca has developed a wide range of heritage outreach strategies (MartínAbad et al. 2017), an objective was made to understand what palaeontological elements were the most appreciated 
Table 1 List of the questions used for the surveys (2010 and 2019). Questions 1 to 3 are demographic categories. In dark grey are the questions added to the poll in 2019. Answers combine binary (yes/no) and open responses. The latter transformed into binary (yes/no, and discrete states) or selected into distinct nominal multiple states

\begin{tabular}{|c|c|c|c|}
\hline VARIABLES & $\begin{array}{c}\text { ANSWER } \\
\text { TIPOLOGY }\end{array}$ & \multicolumn{2}{|c|}{$\begin{array}{cc}\text { ANSWER CODING } & \text { ANSWER CODING } \\
(2010) & (2019) \\
\end{array}$} \\
\hline 1.-Sex & $\mathrm{W} / \mathrm{M}$ & $\mathrm{W} / \mathrm{M}$ & $\mathrm{W} / \mathrm{M}$ \\
\hline 2.- Age group & $\begin{array}{l}<18 ; 18-35 \\
35-55 ;>55\end{array}$ & $\begin{array}{l}<18 ; 18-35 ; 35-55 \\
>55\end{array}$ & $\begin{array}{l}<18 ; 18-35 ; 35-55 \\
>55\end{array}$ \\
\hline 3.- Origin (birthplace) & Binary & Cuenca/Tourist & Cuenca/Tourist \\
\hline $\begin{array}{l}\text { 4.- What museums do you know in } \\
\text { Cuenca? }\end{array}$ & Open & $\begin{array}{l}\text { Coded } 0-1-2 \text { in MCA- } \\
\text { MUSEUMS KNOWN } \\
\text { Coded } 1 \text { when occasio } \\
\text { museum). Coded } 2 \text { wh } \\
\text { (knows } 2 \text { or more mus } \\
\text { museums is considerec } \\
\text { interest. }\end{array}$ & $\begin{array}{l}\text { neral (Fig. 4, } \\
\text { al visitor (knows } 1 \\
\text { current visitor } \\
\text { ims). Knows } 0 \\
\text { without cultural }\end{array}$ \\
\hline $\begin{array}{l}\text { 5.- Do you know the Museo de Las } \\
\text { Ciencias de Castilla - La Mancha } \\
\text { (MCCM)? }\end{array}$ & Binary & $\begin{array}{l}\text { Coded Yes/No in MC } \\
\text { KNOWS MCCM). } \\
\text { MCCM is known eithe } \\
\text { or scholar visits, or by } \\
\text { mass media) }\end{array}$ & $\begin{array}{l}\text { general (Fig. } 4 \text {, } \\
\text { by individual, familiar } \\
\text { ropaganda (journals, }\end{array}$ \\
\hline 6.- Have you visited the MCCM? & Binary & $\begin{array}{l}\text { Coded Yes/No in MC } \\
\text { VISITED MCCM). } \\
\text { If no visits = No scient }\end{array}$ & $\begin{array}{l}\text { general (Fig. } 4 \text {, } \\
\text { ic interest. }\end{array}$ \\
\hline $\begin{array}{l}\text { 7.- What has specially caught your } \\
\text { attention }\end{array}$ & Open & $\begin{array}{l}\text { All listed literally in } \mathrm{F} \\
\text { The frequency and ter }\end{array}$ & $\begin{array}{l}3(\mathrm{I}) \\
\text { are valuated. }\end{array}$ \\
\hline $\begin{array}{l}\text { 8.- Have you seen fossils in the } \\
\text { museum? } \\
\text { Do you remember any in } \\
\text { particular? } \\
\text { Do you remember where they } \\
\text { came from? }\end{array}$ & Open & $\begin{array}{l}\text { Coded as Yes/No for t } \\
\text { analyses (Fig. 4, MCC } \\
\text { MCCM FOSSIL NAN } \\
\text { All remembered eleme } \\
\text { Fig. } 3 \text { (II). Selected ter } \\
\text { the fossil source can b } \\
\text { (Fig. 5). }\end{array}$ & $\begin{array}{l}\text { MCA-general } \\
\text { SAW FOSSILS, } \\
\text { ts are literally listed in } \\
\text { s and connection with } \\
\text { found at MCA-detailed }\end{array}$ \\
\hline $\begin{array}{l}\text { Have you visited the Museo } \\
\text { Paleontológico de Castilla - La } \\
\text { Mancha (MUPA)? (Q\#9 in } 2019 \\
\text { poll) }\end{array}$ & Binary & $\begin{array}{l}\text { Coded Yes/No in MC } \\
\text { VISITED MUPA). } \\
\text { If no visits = No scient }\end{array}$ & $\begin{array}{l}\text { general (Fig. } 4 \text {, } \\
\text { ic interest. }\end{array}$ \\
\hline $\begin{array}{l}\text { Do you remember any fossil that } \\
\text { caught your eye? Do you } \\
\text { remember where they came from? } \\
\text { (Q\#10 in poll 2019) }\end{array}$ & Open & $\begin{array}{l}\text { Coded as Yes/No for } t \\
\text { analyses (Fig. 4, MUP } \\
\text { SOURCE). } \\
\text { All remembered eleme } \\
\text { Fig. } 3 \text { (II). Selected ter } \\
\text { the fossil source can b } \\
\text { (Fig. 5). }\end{array}$ & $\begin{array}{l}\text { MCA-general } \\
\text { FOSSIL NAME, } \\
\text { ts are literally listed in } \\
\text { s and connection with } \\
\text { found at MCA-detailed }\end{array}$ \\
\hline $\begin{array}{l}\text { 9.- Do you know Las Hoyas? } \\
\text { (Q\#11 in poll 2019) }\end{array}$ & Binary & $\begin{array}{l}\text { Coded as Yes/No for } \mathrm{t} \\
\text { MCA-detailed }\end{array}$ & MCA-general, and \\
\hline $\begin{array}{l}\text { 10.- Do you know other } \\
\text { archaeological or paleontological } \\
\text { sites in Cuenca? } \\
\text { Which ones? (Q\#12 in poll 2019) }\end{array}$ & Open & $\begin{array}{l}\text { Coded as Yes/No for } \mathrm{t} \\
\text { 4), and MCA-detailed } \\
\text { 5). } \\
\text { Listed in Fig. } 3 \text { (III) as } \\
\text { palaeontological sites, } \\
\text { in MCA-detailed (Fig }\end{array}$ & $\begin{array}{l}\text { MCA-general (Fig. } \\
\text { LOCALITIES (Fig. } \\
\text { rchaeological, } \\
\text { nd with selected terms }\end{array}$ \\
\hline $\begin{array}{l}\text { 11.-In your opinion, how the } \\
\text { dissemination of information } \\
\text { about sites and fossils could be } \\
\text { improved? (Q\#13 in poll } 2019 \text { ) }\end{array}$ & $\begin{array}{l}\text { Open with } \\
\text { options. }\end{array}$ & $\begin{array}{ll}\circ & \text { More activitic } \\
\circ & \text { Visits to the } \mathrm{s} \\
\circ & \text { Activities in } \mathrm{t} \\
\circ & \text { Other respons }\end{array}$ & $\begin{array}{l}\text { in the Museum } \\
\text { schools } \\
\text { (Future expectations) }\end{array}$ \\
\hline
\end{tabular}


Fig. 3 Changes from 2010 (a) to 2019 (b) on the survey's open question (I-III). The answers (in percentage) are grouped by issues with its respective colour a

b

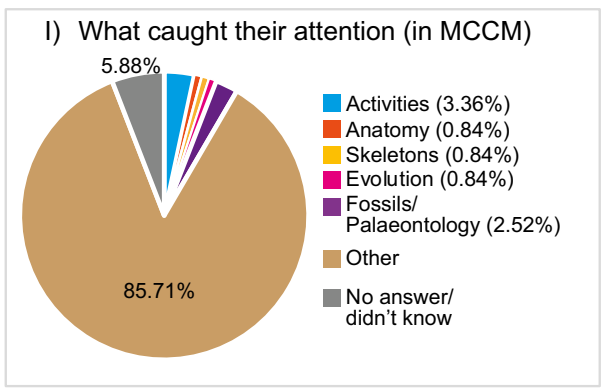

I) What caught their attention (in MCCM)

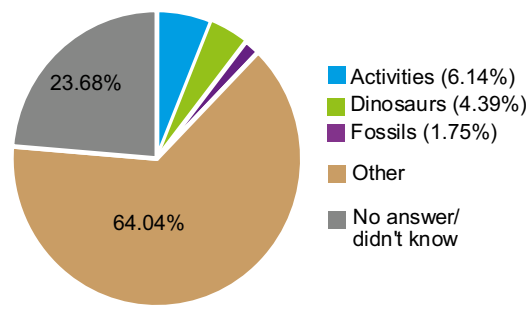

II) Remembered a fossil (from MCCM)

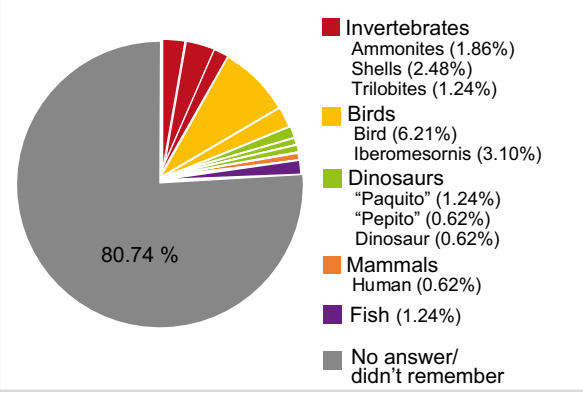

III) Knows Cuenca's localities

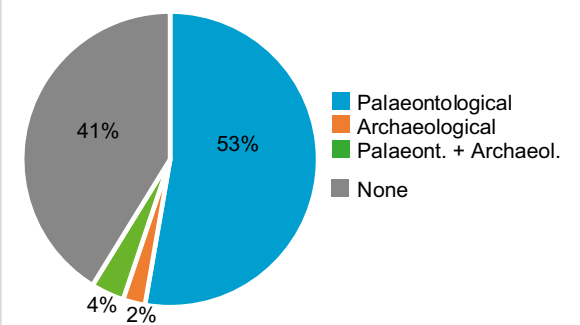

II) Remembered a fossil (from MUPA)

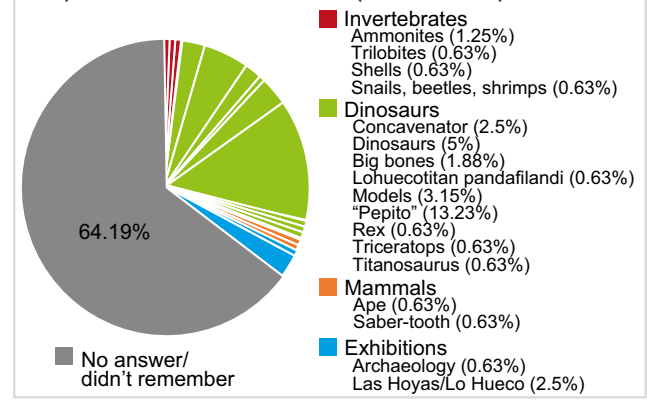

III) Knows Cuenca's localities

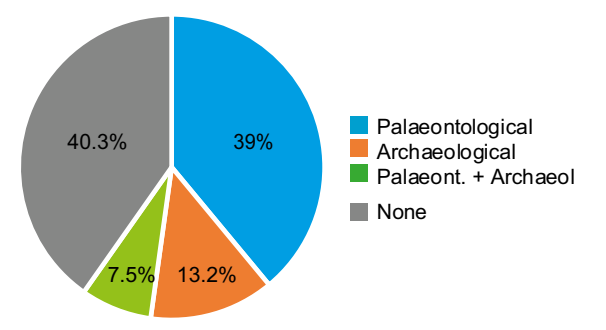

by its citizens: the most well-known fossil sites, fossils or dinosaurs.

Categorisation of the Responses In the survey, data was collected on what citizens remembered from their experiences and what concepts, species and terms they selected. The first three questions (\#1 to \#3 in both surveys) comprised the set of demographic questions. The responses were categorised into different groups to homogenise data for subsequent statistical analyses (Table 1).

(1). The number of museums that people could recall and the number of people who visited Cuenca's science museums (\#4 to \#6), with the addition of the MUPA in the 2019 survey (\#9 in 2019). The answers collected from this set of questions provided information about (a) the frequency with which the respondents visited Cuenca's museums or if they were interested in them, regardless of the type of museum (Art, Religion or Science). When the respondent named only one, it was considered an occasional museum visitor (receiving a value of 1); when they recalled more than two, it was interpreted as a cultural practice (receiving a value of 2); when no answer was provided, it was considered as ignorance (receiving a value of 0 ). (b) Their general interest in science when they mention MUPA and/or MCCM museums (YES if mentioned, NO if unknown).

(2). What caught their attention (\#7). In this question, we compared all the terms we gathered from both surveys (Fig. 3-I). An assessment was made regarding what terms respondents preferred the most, the variety of the names used and their scientific contexts (i.e. evolution, palaeontology).

(3). How many people who had visited the science museums remembered seeing fossils and how much information about them they could recall (\#8 in 2010 and \#8 and \#10 in 2019). The answers were all listed (Fig. 3-II) and used in the detailed MCA analysis (Fig. 5). The responses were considered according to the nature of the answers $(\mathrm{a}-\mathrm{c})$ and as they reflected a fossil-locality connection (d): 
Fig. 4 General Multiple Correspondence Analyses (General MCA); a 2010, the $>55$ age group is indicated by a white arrow and clearly separated from the rest; b 2019, the exceptional group called "Paleogeeks" is indicated by a black arrow. Significant demographic categories are set in a highlighted circle a

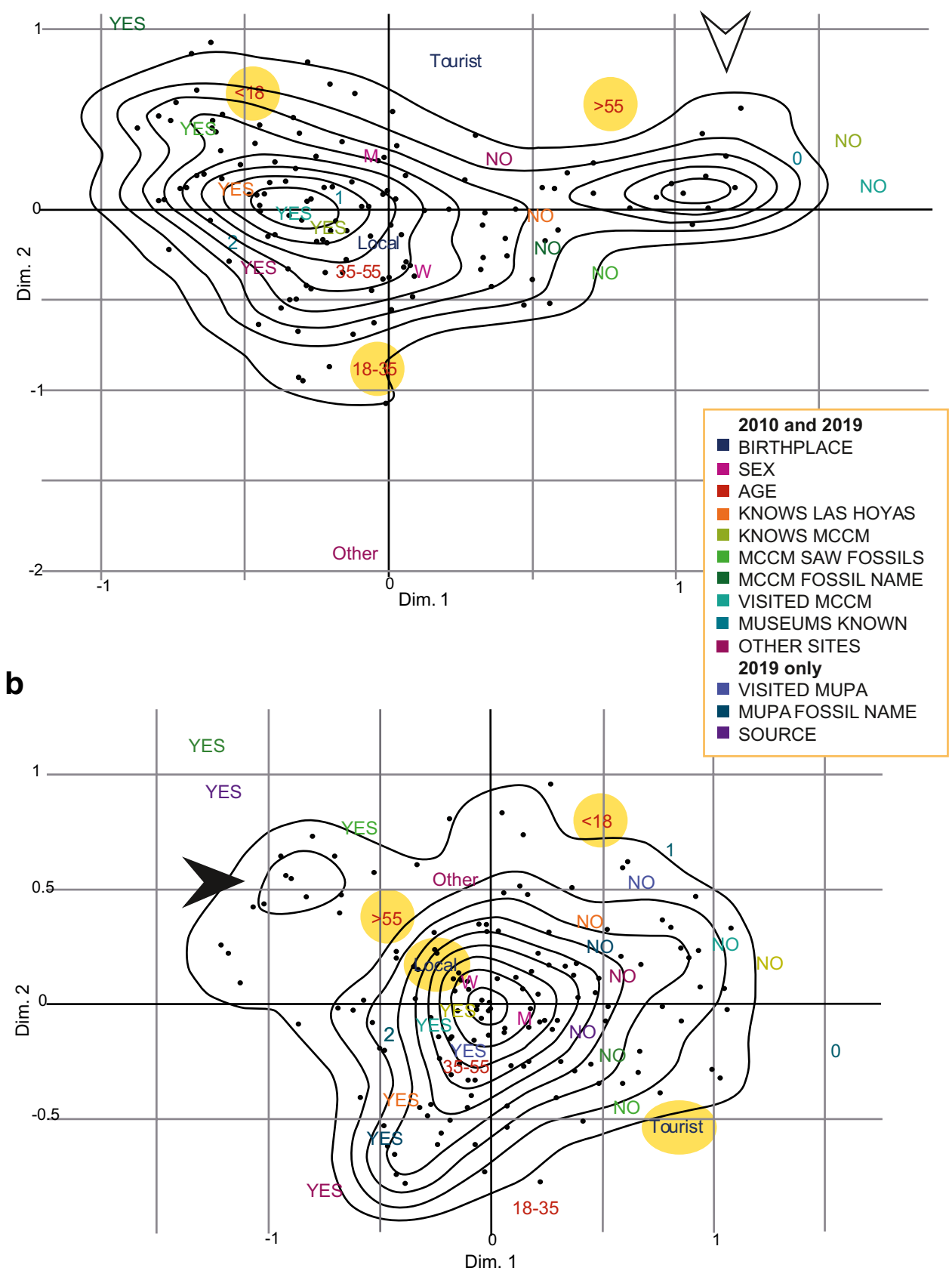

(a) Taxa: Singular scientific terms such as ammonites (see Fossil-Ammonites in Fig. 5), trilobites, apes/ humans, dinosaurs in general (e.g., dinosaur, Triceratops, Titanosaurs, T. rex), specific local dinosaur species (Lohuecotitan, Concavenator) and Iberomesornis, a famous local fossil bird. The answers were rated according to the precision of the terminology the respondents used-if they had addressed the different local species by their scientific name- and/or the frequency of dinosaurs as the preferred choice. (b) Nicknames: The mention of informal names which were turned into nicknames that everyone uses was analysed separately. The nicknames (see Wolny 2011 for definitions) given by palaeontologists in their research in Cuenca may represent either an unofficial species name (e.g. 'Pepito' for Concavenator) or a functional particularity of the named species (e.g. 'Corretón'-the runner-for Pelecanimimus) (Sanz et al. 2015).

(c) CABS: When the fossils were identified easily because of them resembling living animals 
Fig. 5 Detailed Multiple Correspondence Analyses (Detailed MCA); a 2010, most answers are gathered in the centre; $\mathbf{b}$ 2019, although answers are concentrated around the centre, some respondents start to separate (indicated by a black arrow) a

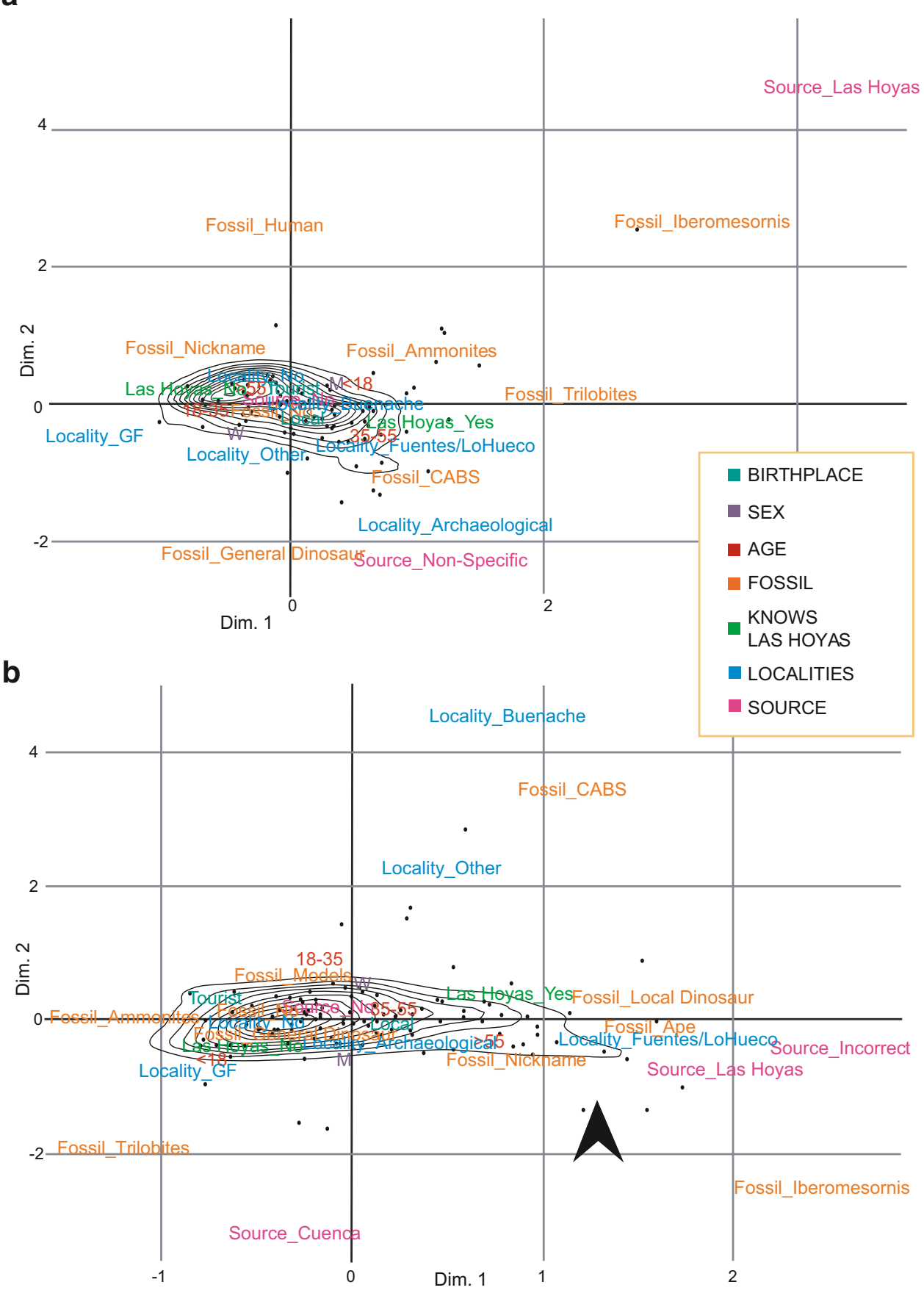

(e.g. fish, birds, insects, shells, snails, shrimps or butterflies), the responses were included in the analysis as CABS (Contemporary Animal Body Shapes). When grouping all these names, a distinction was made between 'easy fossils', as defined by Rudwick (2008), and 'difficult fossils' (organisms with a more complex shape, such as trilobites or ammonites). Respondents who are educated or who are interested in culture are likely to remember 'difficult fossils'. The last option was 'No' (the respondent did not remember).

(d) Sources: The source of origin of the fossils. The purpose of exploring this was to assess the ability of the respondents to link related topics. For instance, if presented with the locality of Las Hoyas and one of its fossils, respondents had to try to think of the connection between them. Responses with a non-specific relationship 


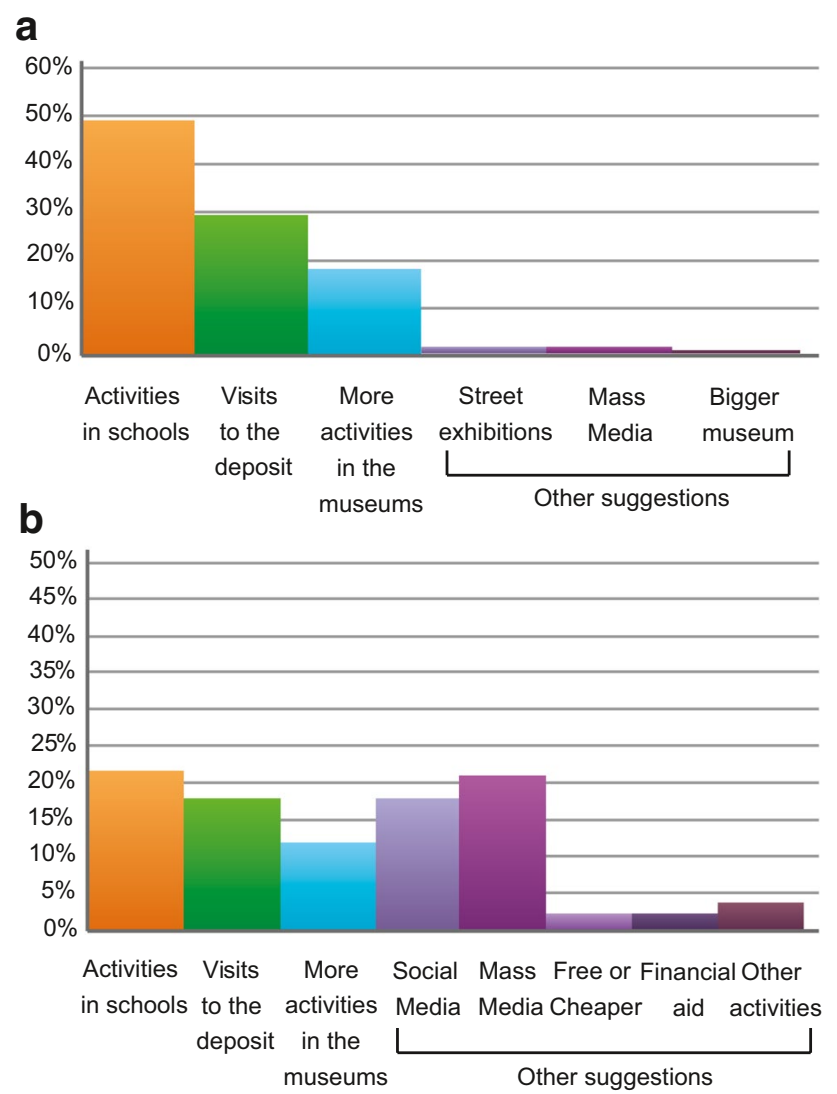

Fig. 6 Answers on how to improve palaeontological outreach in Cuenca, and other suggestions; a 2010; b 2019. The interest of visiting palaeontological sites is practically maintained

between source and fossil or where the respondent could not recall the connection were considered as another character state.

(4). How many people knew famous Cuenca localities (whether they were archaeological or palaeontological sites), including an explicit mention if they remembered the name of Las Hoyas (\#9 and \#10 in 2010 and \#11 and \#12 in 2019). Within localities, the following selection was made:

(a) Famous fossil localities found in Cuenca or nearby, such as Las Hoyas, Buenache and Lo Hueco (Fuentes). These are, in fact, the three best-known fossil localities. Respondents who were able to name well-known localities probably had a certain interest in the topic-or they were informed about heritage (through museums and mass media).

(b) Other fossil sites that are less known by the public but were occasionally mentioned. These are localities with discovered fossil remains (e.g. sauropod eggs from Buendía) or stages of palaeontological routes like the dinosaur route.

(c) Geological formations (GF), like La Ciudad Encantada (a natural Spanish landscape of limestone rock formations), were erroneously named as fossil localities.

No' (the respondent did not remember) also was assigned.

(d) Archaeological sites were taken into account to observe how many people named archaeological deposits and to see if they were often mistaken by palaeontological ones.

(5). The perception on the quantity and quality of the different outreach actions (and suggestions on how to improve them) corresponds to questions \#11 in 2010 and \#13 in 2019. It was a question where respondents had to choose between three options, although they could select more than one option or write about their future expectations. Through this question, it was explored:

(a) If they were interested in receiving more detailed information.

(b) If they had an informed opinion on the different outreach initiatives already implemented.

(c) Through which medium they preferred to receive relevant content.

\section{Statistical Methods}

Statistical analyses were performed with R. They consisted of tests that compared qualitative variables (Pearson's chi-square test and Fisher's exact test) to analyse the link between pairs of variables - one of the group-differentiation variables and one of the variables of interest (Blanco 2011). Post-hoc analyses were carried out whenever a result was significant ( $p$-value $<0.05)$ by looking at the residuals of the chi-square test, with the assocstats function. Two multiple correspondence analyses (MCA) from the FactoMineR package (Husson et al. 2020) were provided: general MCA (Fig. 4) and detailed MCA (Fig. 5). Each analysis was based on a different data matrix (see Online Resource 3). For the general MCA, the variables were coded as binary states (see Table 1), whereas in the detailed MCA, the answers in certain significant variables (locations, dinosaurs and fossils) were categorised into a set of multiple nominal states. In both cases, the demographic variables were incorporated like any other variable.

MCA is an exploratory multivariate method that evaluates the relationships between the different qualitative variables. To visualise the resulting trends, the ggplot function was used. In this graphical analysis, each of the individuals is 
represented by a dot, distributed around the values of the variables that portray their responses. The ellipses represent groups of respondents that gave similar responses; those who provided very different answers appear far apart and form a separate group of ellipses.

\section{Results}

Results will be delivered in the same order as the statistical analyses.

\section{Survey}

The main significant trend (See Online Resource 4) was linked to age: younger age groups ( $<18$ and 18-35) were able to name more museums than people from older age groups. Also, significantly more young people had visited the MCCM, whereas older respondents (over 55 years old) had not-with few exceptions. Many of the older respondents were unable to recall more than two museums. Younger people knew the Las Hoyas site, but only a few people older than 55 years recalled it or other famous palaeontological sites, and none of them named any archaeological sites. Las Hoyas locality was significantly better known by men than by women, but there was no significant difference in the knowledge of Cuenca's heritage between locals and visitors.

The non-significant trends (Fig. 3a) correspond to questions \#7, \#8 and \#10: visitor's attention (I), remembering a fossil (II) or remembering a fossil locality (III). (I) Only 14.29\% (from 119 MCCM visitors) recalled words such as anatomy, skeletons, fossils and evolution. (II) $24.36 \%$ recalled a specific fossil. However, they were frequently unable to designate scientific species, referring to generic names of easily recognisable fossils, such as shells, fish, birds or humans. Surprisingly, dinosaurs were not the most identified, and sometimes one of the species, Concavenator corcovatus, was named by its nickname 'Pepito' (some respondents erroneously called it 'Paquito'). Nonetheless, several people were aware of Cuenca's well-known fossils, such as the Mesozoic bird Iberomesornis romerali, and other more specific answers included ammonites and trilobites. (III) More than half of the respondents (53\%) named a palaeontological site, whether it was Las Hoyas or any others, such as Lo Hueco (Fuentes) or Buenache. Some people (6.29\%) were able to name an archaeological locality. Many people did not know any site (41\%). Just one person out of the 159 respondents precisely remembered that the fossils in MCCM came from Las Hoyas.

The 2010 general MCA (see Online Resource 4 for variables' contribution) shows two groups of individuals (Fig. 4a). First, a small group distributed around the negative values of several variables and close to the $>55$ value of the age variable. People found within this variable are mostly older and could not answer or could not give a precise enough response to most (if not all) of the questions. The most striking thing found in this subset is that, even though all individuals were natives of Cuenca, the interest in their heritage, and most precisely, in scientific and palaeontological knowledge, was alarmingly low. Although many people in this group knew some of the palaeontological sites of the region, they did not seem to show any interest in the research or in the fossils found, since they did not visit the museum where these fossils were displayed. This subset corresponds to $12 \%$ of the total of the respondents, and it represents $15 \%$ of the respondents who were born in Cuenca. Secondly, a larger group of respondents with a general cultural knowledge, located nearer the centre of the graph, and those located towards positive values denoted interest in heritage, science and palaeontology. This last subset corresponds to the younger age groups (aged $<18$ and 18-35) and adults (aged 35-55), consisting of natives and tourists. Most of these respondents named two or more museums; all of them had visited the MCCM and were able to name some of the exhibited elements, showing interest in scientific knowledge. Even though this subset seemed to pay attention to exhibits, the palaeontology and evolution exhibit was not so popular, as the planetarium was the preferred draw at the MCCM.

In the detailed MCA (see Online Resource 4 for variables' contribution), most respondents can be found towards the centre of the graph, indicating very general answers (Fig. 5a). In 2010, the more specific answers (knowing that MCCM fossils came from Las Hoyas or naming fossils by their scientific name like Iberomesornis) were so rare that they almost do not accumulate values around them. This limited selection of respondents belonged, for the most part, to the $<18$ and $35-55$ age groups, men being slightly more numerous than women. Locals and tourists are virtually all together in the centre, indicating no significant differences in their responses.

The last question about what could be done to increase palaeontological outreach (Fig. 6a) revealed the following results: $49.5 \%$ of the respondents considered that schools were the most suitable places to implement outreach initiatives, 29.9\% showed interest in visiting the fossil sites, but only $1.9 \%$ thought that mass media and advertising should be the main means to promote heritage.

\section{Survey}

The 2019 survey shows different trends from 2010; chisquare and Fisher's analyses (see Online Resource 4) denoted that now Cuenca natives can name more museums, they have visited them and they remember the exhibitions and can list more localities than tourists. In addition, 
older-age groups $(35-55$ and $>55)$ were the ones who performed significantly better, since they answered more questions and in a more precise manner: they named more museums, knew more fossiliferous localities and could recall at least one fossil name. Additionally, whereas in 2010, teenagers were the ones who had a deeper and more complete knowledge, in 2019, they performed the worst, even though approximately the same number of younger and older people visited both the MCCM and MUPA. There was no significant difference between sexes.

Other non-significant trends (Fig. 3b) show (I) that, when asked about what they remembered seeing in the MCCM, $6.14 \%$ of respondents recalled the fossils that were moved to the MUPA. However, most people (64.04\%) stated that other exhibitions (unrelated to fossils) caught their attention. (II) $35.22 \%$ of respondents were able to recall a fossil, and most of them $(80.4 \%)$ mentioned dinosaurs. They alluded to the fossils using common names or nicknames given by mass media and museum guides; for example, $37.5 \%$ of respondents referred to Concavenator corcovatus as 'Pepito'. Only a small percentage $(6.29 \%)$ was able to point out the scientific species. (III) Less than half of the participants named a palaeontological site (39\%), whether it was Las Hoyas or any others, such as Lo Hueco (Fuentes) or Buenache. Some of the respondents knew an archaeological site (13.2\%), and many of them did not know any (40.3\%). Just 15 people in the whole 2019 group (formed of 159 people) gave precise answers in relation to the fossil site and taxa.

The general MCA (see Online Resource 4 for variables' contribution) depicts that neither the variables nor the individuals are grouped on one side of the graph; they are dispersed, with just a small group barely separated (Fig. 4b). Also, most of the respondents are located around the centre of the graph, suggesting diffuse, vague answers that do not link related concepts. The groups of younger ages are located on the negative (NO) values of many variables (positive side of Dim. 1), while older age groups are on the positive (YES) values (negative side of Dim. 1), portraying the better performance of older people over young people and confirming the results obtained in the chi-square or Fisher's tests. The small subset of the sample (6.28\% of respondents), encompassed within the main group, is highlighted in the graph (left top, Fig. 4b). These few individuals answered in a precise way, linking related topics and palaeontological concepts, such as taxa and fossil site. When asked about a specific fossil, they mostly mentioned dinosaurs (many of them used nicknames), but a couple of them cited the Mesozoic bird Iberomesornis romerali.

In the detailed MCA of 2019 (see Online Resource 4 for variables' contribution), it can be observed that some respondents are gathered around the centre of the graph, but there are other answers that are separated from the centre and make the graph take an ellipsoidal shape (Fig. 5b).
In 2019, the answers regarding the fossils in Cuencathat is, naming local dinosaurs by their scientific name (Local Dinosaur), a local cretaceous bird (Iberomesornis), and naming local fossils by their affectionate name (Nickname) - centre around knowing Las Hoyas and Lo Hueco, which are the sites that have a section in the MUPA exhibition and approximate responses relating these fossils to their provenance (Source). Therefore, these answers are more precise and linked to a better knowledge of heritage, sites and fossils. The respondents who gave these answers belong to the oldest age groups $(35-55$ and $>55)$ born in Cuenca (Local). Tourists and young people (18-35 and especially $<18$ ) are grouped around the negative values of the studied variables, indicating a less specific discourse linked to knowing few or no sites. From their responses, it seems that these groups only retained general concepts, as they referred to fossils as contemporary animal body shapes (CABS) or fossils commonly seen in palaeontology museums (such as ammonites or trilobites); sometimes, they also recalled non-local but popular dinosaurs (General Dinosaur, like T-rex) or objects that are flashy at first sight (Models). Women and men are virtually together in the centre, indicating no significant differences in their responses.

As for the answers on how to increase palaeontological outreach and impact (Fig. 6b), 47.4\% of the respondents provided different suggestions outside the given options (the main recommendation was advertising more through social media and mass media); $21.9 \%$ considered that palaeontology and science activities should be carried out in schools, and many expressed an interest in visiting the fossil site $(18.75 \%)$.

\section{Discussion}

Our results display a positive trend: an increase in Cuenca citizens' interest in science. From 2010 to 2019, a significant change was noticed in people's palaeontological knowledge and experiences, memories and opinions. In this study, we effectuated a progressive analysis of the collected responses $(N=340)$ by using multivariate MCA techniques, starting with simple binary states and transforming the open responses into multiple nominal states. The Yes/No responses provided a broad picture on the patterns of citizen's palaeontological interest. Conversely, the open questions gave the opportunity to explore the vocabulary respondents used to designate what surprised them and what they remembered from the science museums (MCCM and MUPA). Therefore, this twofold survey has proven to be effective at characterising the profiles of Cuenca's inhabitants and the way these change over time. 
To represent and to understand the scientific profiles of Cuenca's people, the age category is critical, as the results showed significant disparity when age groups were compared. Furthermore, the vocabulary used suggests a shift from formal to more informal terms from 2010 to 2019. It was generally found that the majority of the answers were congruent within the same timescale and corresponded with the sociocultural changes that Cuenca had experienced, from a rural to a more urban and diverse culture. The impact of heritage outreach initiatives observed in the results is considered to influence the scientific profiles of Cuenca's inhabitants. This opens the door to discussing what elements Cuenca's citizens may share with people from other small European Historic Urban Landscape localities which are also within close proximity to a famous palaeontological site.

\section{Age Disparity}

The 2010 survey revealed vast differences in information and responsiveness between older and younger participants, the latter showing a superior level of understanding. Older people $(>55)$ suffered from the consequences of an educational gap (many of them not having completed primary/secondary school) that was progressively mitigated from the 1970s onwards, thanks to Education Laws in Spain (Pascual-Barrio 2006). Of course, it would have been better to ask about the educational level as one of the demographic questions in the survey, but it was considered that question to be a sensitive matter for people with lower education (European Social Survey 2011). Strikingly, in 2019, older people (35-55 and $>55)$ answered more precisely than young people $(<18)$, hence showing greater interest and appreciation in scientific topics. Nowadays, (i) older people are no longer affected by educational inequality; in fact, in 2019, they delivered quite precise answers when asked about their heritage and showed great interest around scientific topics. By contrast, (ii) teenagers were the ones who performed the worst. The negative results of teenagers $(<18)$ were in concordance with the low scores in science obtained by Spanish students, significantly below the 2019 OECD average (Ministry of Education and Professional Training 2019) (see Online Resource 1). It has been addressed that these low academic results were highly related to the national socioeconomic circumstances of the time (Gamazo and Martínez-Abad 2020), which worsened during the 2008 crisis and its subsequent austerity policies (compare in Fig. 1c the National and Castilla-La Mancha expenditure diagrams, also see The Local 2019). The respondents who belonged to the group of $<18$ in 2019 were completely new people who were not represented in the 2010 data matrix. Also, all the individuals who belonged to the group of $<18$ in 2010 have become part of the next age group (18-35) 10 years later.

Additionally, the 2019 survey showed a statistically outlying group composed of individuals of different ages (average age being around 35 years, which means most of them belonged to older groups) who were able to provide many precise answers. This group (herein named 'paleo-geeks', observed in Figs. $4 \mathrm{~b}$ and $5 \mathrm{~b}$ ), although not entirely separate from the main group, was significantly successful when it came to linking specific local fossils to the sites where they were discovered ( $p$-value $=0.0004998$; see Online Resource 4), especially in the case of dinosaur fossils. The accuracy of some of their responses could not have been achieved without prior interest in the topic.

More age disparities were identified while analysing the terms obtained from the open questions. First of all, the high number of 'No' and 'I don't know' responses (Fig. 3) should be pointed out, with it constituting more than $65 \%$ of the total. As for the rest of the answers, a tendency emerges. In 2010, the vocabulary used by respondents to designate which museum elements surprised them and which they remembered, although less diverse, included more accurate words, with some isolated technical names and terms they likely learnt at school (Fig. 3a). In 2019, the names were more general but more diversified (Fig. 3b). This may indicate a disparity in the narratives of the visitors between the surveyed years. In 2010, the answers, most of them from younger respondents (around 20 years on average), were likely to reflect concepts that were taught at school. Those who remembered fossils (Fig. 3a-II) referred to them as (1) petrified animals with similar body shapes to contemporary beings (CABS), like birds, shells and fish, but also as (2) weird animals with geometrical and clear forms such as ammonites and trilobites. The high proportion of same names suggests that visitors found something positive in the visit since it reinforces the idea they had of a fossil in their memory. Few respondents mentioned dinosaurs or their local nicknames. However, the narrative outlined in 2019 suggests that the answers were rather focused on local heritage, since most of the respondents recalled the local dinosaurs and their nicknames (compare Fig. 3a, b). A notable increase in the use of palaeontological names (and in eloquence to recall them) can be observed. Even if the better answers came (on average) from older groups ( $35-55$ and $>55$ ), the diversity of ages of respondents who named fossils shows that richer personal experiences, emotions and memories are taking place.

The concept of narratives was proposed by Doering and Pekarik (1996) to categorise the self-reinforcing motivations people express when visiting a museum. With the established idea that individuals bear a previous body of knowledge and identity, the development of the narrative's analysis based on post-visit individual interviews is currently applied to categorise the motivations of the museum visitors (Falk and Gillespie 2009; Falk 2016; Rowe and Nickels 2011; Vesci et al. 2020). In this research, no attempt was made to identify any motivations, but respondents who used a certain vocabulary provided indirect evidence on this - motivations could be inferred by the way they remembered concepts and felt about them. Therefore, whereas in 2010, the maxim was 'education', in 2019, the plausible maxim 
shifted to 'entertainment'. In the first survey, reasons and emotions were propelled by an interest in knowledge; in the second survey, they were a result of pride in Cuenca's heritage and the desire to enjoy it. These emotions are indeed driven by the local dinosaurs and fossil sites.

The isolated group consisted of respondents who gave a large number of precise responses was referred to as 'paleo-geeks'. It is clear that the media have boosted the popularisation of dinosaurs by the usage of nicknames that attract people to exhibitions (Allmon et al. 2012) —nicknames that museum instructors then feed to visitors. Paleo-geeks are probably most influenced by the popularity of dinosaurs in Pop Culture (Buscalioni 2015; Sanz 2002), and they correspond to a wide spectrum of ages, although mainly focused on people in their $30 \mathrm{~s}$. This group conforms with the definition of 'geek', as enthusiasts of a particular subject or field, with an interest in collecting and gathering data and memories related to their topic of interest (Pardo 2013) and being technologically skilled. It would be worthwhile to explore in depth and better characterise this cultural subgroup around palaeontology in Spain.

\section{Sociocultural Change and Heritage Outreach Impact}

The differences between the 2010 and 2019 results also indicate a socio-cultural change in Cuenca, from a rural culture to a more urban and diverse one, with a higher per capita Gross Domestic Product (from 19,329€ in 2010 to $22,691 €$ in 2018). This socio-cultural shift is in consonance with the mechanisms put in place to invigorate rural communities (Díaz-Puente et al. 2012) and also with the continuous development of Cuenca's historical area since 1996, when it was declared World Heritage City (González-Oñate and Martínez-Bueno 2013). This change is also corroborated by the great attention paid to social media channels, which are quite active-MCCM has 1860 followers on Facebook and MUPA has 4893 on Facebook, 1634 on Twitter and 1716 on Instagram. Heritage outreach seems to be part of this socio-cultural change too, resulting in significant consequences in Cuenca. This statement is supported by the presence of the 2019 paleo-geek group, of whom 75\% are natives of Cuenca. The local fossils, and especially the famous fossil localities (see Figs. 2, 3 and 5), represent an important sociocultural value, to the point that these elements of palaeontological heritage have become a sign of identity.

The presence of museums and the proximity to the countryside allow locals to live new cultural experiences, which probably makes them care about their heritage. Every famous European Palaeontological site like Cuenca has its own indigenous dinosaurs, which are known by their nicknames. The Italian locality of Pietraroja is famous for the dinosaur Scipionyx samniticus, with preserved soft tissue (Dal Sasso and Signore 1998); this Italian dinosaur is known as 'Ciro'. Concavenator corcovatus is famous because of its skin preservation and its prominence at the back of the sacral region (humped dinosaur)
(Ortega et al. 2010), and it is known as 'Pepito'. The nicknames identify the dinosaurs as the local protagonists, with an epic name or with a very common person's name. The usage of a nickname is related to an intimate, familiar treatment which is a characteristic of small groups or close-knit communities (Wolny 2011). These famous European Palaeontological dinosaurs are a symbol of uniqueness, a local natural monument linked to the geological features of the locality, and/or a living icon that enriches popular culture. For example, Concavenator, although only briefly, appears as a statue in the movie Jurassic World: Fallen Kingdom - an Easter egg that did not go unnoticed by the local media (Lozano 2018).

\section{A Schema of Cuenca's Scientific Profiles}

Considering all the elements of heritage outreach (i.e. formal and non-formal education, research dissemination and mass media), we analysed the data obtained from Cuenca's inhabitants in order to represent their scientific profiles (Fig. 7). The construction of the 2010 profile began with the evidence that inhabitants from older age groups $(>55)$ did not find neither compulsory education nor mass media relevant enough and that the information they managed was scarce (Fig. 7a). From this 'negative' profile, the increase in interest is manifested in the age groups formed by young people and adults (from ${ }^{<} 18$ to $35-55$ years old), which are congregated towards the centre of the graph (Fig. 7b). Because these age groups were more receptive to scientific messages (regardless of their birthplace), it was believed that cultural actions, both in and out the classroom, fostered scientific knowledge. However, in 2010, the palaeontological interest behind the visit to the MCCM was scarce, both at the general and local levels, suggesting that most probably scholars were the only group encouraged to visit the palaeontological exhibition at the MCCM. Therefore, education and outreach would be the main drivers behind visits to the MCCM during that year, and that first visit could motivate people to visit the museum again, confirming what they learnt and encouraging these groups to delve deeper into the topic.

The profile diagram changed in 2019 (Fig. 7c) because locals performed better, probably influenced by the opening of a new palaeontological museum. Furthermore, the new exhibition focuses on the fossils and sites near the city. The change in 2019's profile can be explained assuming that compulsory education encourages museum visits and promotes scientific appreciation, now affecting all age groups equally, but when it comes to drawing attention to scientific topics, mass media and especially social media would have a great influence. Schools ensure a basic knowledge of every subject, but searching for specific facts only occurs when specialised concepts are taught in a different environment and when people's attention has been captured (Yasunaga 2014; Scheersoi 2015). 
a

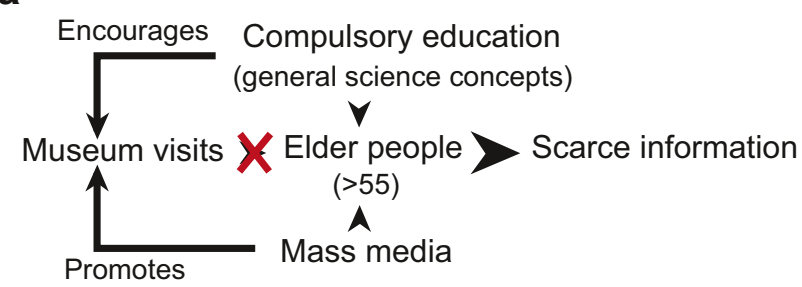

b

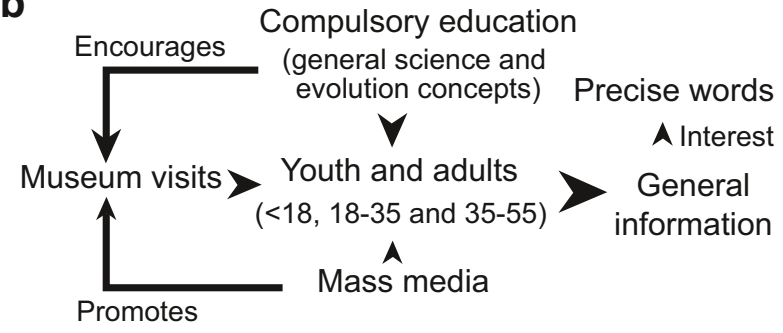

C

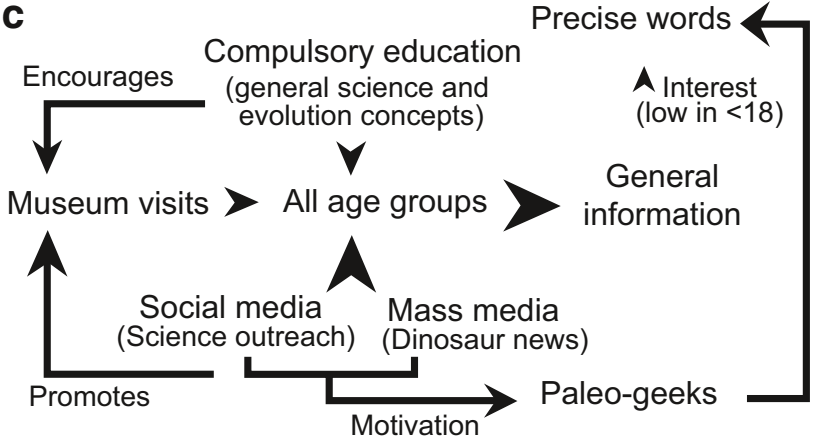

Fig. 7 Scientific profiles ordered from low to high interest in the city of Cuenca (Spain); a elder people do not have much interest in visiting the museums in 2010; b teenagers, young and parent groups (from $<18$ to $35-55$ ), the education and museum visits play an important role in 2010; c a homogeneous base occur for all groups in 2019 with strong influence of media. The size of the arrows indicates greater or less contribution to the factor they point

In an attempt to encourage scientific literacy among the general population, heritage outreach initiatives strongly support incorporating issues related to natural history and evolution into the public domain. For instance, the 3D interactivity of the anatomy of Scipionyx is a useful and versatile educational tool (Manucci et al. 2019). However, the dominance of mass media news has the risk of fixing superficial scientific knowledge. The responses obtained revealed that respondents' scientific knowledge was superficial, being the following the main issues: (i) quite scarce knowledge of extinct and past groups other than dinosaurs; (ii) inability to discriminate between archaeological and palaeontological study fields; (iii) disconnection between fossils, their origin and age and (iv) inability to correctly link the names of the species with their biological group. Moreover, the usage of nicknames also separates dinosaurs from their scientific context. Nicknames, in general, deprive biological names of their relevance for understanding the geological, ecological and evolutionary processes that guarantee the delivery of rigorous and complete knowledge (Valdecasas and Correas 2010).

\section{Conclusions}

We can elucidate, therefore, that palaeontology is increasingly important to Cuenca's culture, becoming one further attribute among history, geography, institutions, beliefs, etc., in the building of personal and community identities. The actions developed in Cuenca during the last 10 years have successfully awakened citizens' pride in their heritage and identification with it and have encouraged a greater scientific interest in fossils. Compensatory social policies have influenced people's knowledge about heritage in two different contexts: an early step in Education fostering the motivation of students and a further step in Culture boosting the general public's interest, represented by the exceptional group of paleo-geeks. This progress in Culture is tightly related to the spreading of information through mass and social media. However, a shallow knowledge and understanding of the biological meaning of the species, their ecology and evolution was perceived. It was found that the results of the statistical analysis of the responses were consistent with other sociocultural changes observed in Cuenca, from a rural to a more urban and diverse culture. It is presumed that similar European localities bearing a Historic Urban Landscape heritage like Cuenca will render equivalent differential narratives. It is also believed that the differences between localities will depend on the impact of the activities carried out by research teams with clear scientific objectives. New heritage outreach strategies should be planned in order to gain a deeper knowledge on how diversity from the past is perceived.

Supplementary Information The online version contains supplementary material available at https://doi.org/10.1007/s12371-021-00568-6.

Acknowledgements The authors would like to acknowledge Francisco José Serrano Alarcón, Álvaro López García, Aitor Sopelana Salcedo and Ioannis Sarris for conducting the 2010 surveys. The authors would also like to thank Ana Cristina González Martín and Carl Eadie for assessing the translation of this work and the reviewers for their valuable comments and discussions which improved the quality and clarity of this paper.

Funding Funds provided by YEI Programme of the Community of Madrid (PEJ-2018-AI/AMB 10951), Provincial Government of Cuenca (BOPC, 149 30/12/2019), and Ministerio de Ciencia e Innovación PID 2019-105546 GB-I00.

Data availability Databases with the categorised responses used for statistical analyses are available as supplementary information. Due 
to the personal nature of the answers provided by the respondents in this study, the authors consider that public access to the original data may be a sensitive issue. However, we encourage those particularly interested to contact the authors.

Code availability Not applicable.

\section{Declarations}

Competing interests The authors declare no competing interests.

Open Access This article is licensed under a Creative Commons Attribution 4.0 International License, which permits use, sharing, adaptation, distribution and reproduction in any medium or format, as long as you give appropriate credit to the original author(s) and the source, provide a link to the Creative Commons licence, and indicate if changes were made. The images or other third party material in this article are included in the article's Creative Commons licence, unless indicated otherwise in a credit line to the material. If material is not included in the article's Creative Commons licence and your intended use is not permitted by statutory regulation or exceeds the permitted use, you will need to obtain permission directly from the copyright holder. To view a copy of this licence, visit http://creativecommons.org/licenses/by/4.0/.

\section{References}

Allmon WD, Ross RM, Kissel RA, Kendrick DC (2012) Using museums to teach undergraduate paleontology and evolution. Paleontol Soc Special Publ 12:231-246. https://doi.org/10.1017/S2475 262200009345

Blanco C (2011) Encuesta y estadística: métodos de investigación cuantitativa en las ciencias sociales y comunicación. Córdoba: Editorial Brujas

Buscalioni AD (2015) El Paleoarte, entre arte público y cultura popular. eVOLUCIÓN 10(2):71-81

Cuenca JM, Domínguez CD (2005) Patrimonio e identidad para un espacio educativo multicultural: análisis de concepciones y propuesta didáctica. Investigación en la Escuela 56:27-42. https:// doi.org/10.12795/IE.2005.i56.03

Dal Sasso C, Signore M (1998) Exceptional soft-tissue preservation in a theropod dinosaur from Italy. Nature 392:383-387

de la Cita L and Buscalioni AD (2019) LAS HOYAS. Portal de Cultura de Castilla-La Mancha. https://cultura.castillalamancha.es/patri monio/yacimientos-visitables/las-hoyas. Accessed 20 Apr 2020

Díaz-Puente JM, Gallego FJ, Vidueira P, Rocco-Aguilera A (2012) Information as a key tool for rural development. 25 years of experience in Spain. Procedia Soc Behav Sci 46:1208-1212. https:// doi.org/10.1016/j.sbspro.2012.05.276

Doering ZD, Pekarik AJ (1996) Questioning the entrance narrative. J Museum Educ 21(3):20-23. https://doi.org/10.1080/10598650. 1996.11510333

European Social Survey (2011) European Social Survey data and documentation. https://www.europeansocialsurvey.org/data/. Accessed 7 Feb 2020

Falk J (2016) Museum audiences: a visitor-centered perspective. Loisir Soc 39(3):357-370. https://doi.org/10.1080/07053436.2016. 1243830

Falk J, Gillespie KL (2009) Investigating the role of emotion in science center visitor learning. Visitor Stud 12(2):112-132
Gamazo A, Martínez-Abad F (2020) An exploration of factors linked to academic performance in PISA 2018 through data mining techniques. Front Psychol 11:3365

González-Oñate C, Martínez-Bueno S (2013) La marca territorio como elemento de la comunicación: Factor estratégico del desarrollo turístico en Cuenca. Pensar la Publicidad 7(1):113-134. https:// doi.org/10.5209/rev_PEPU.2013.v7.n1.42439

Guerrero-Arenas R, Arellano FJA, Mendoza LA, Jiménez-Hidalgo E (2020) How is the paleontological heritage of Mexico and other Latin American countries protected? Paleontol Mex 9(2):83-90

Hermoso B (2020) La ciudad de Cuenca en imágenes, un museo infinito. El País. https://elpais.com/videos/2020-12-15/la-ciudad-de-cuenca-en-imagenes-un-museo-infinito.html. Accessed 9 Mar 2021

Hibberts M, Burke Johnson R, Hudson K (2012) Common survey sampling techniques. In: Gideon L (ed) Handbook of Survey Methodology for the Social Sciences. New York: Springer, pp 53-74

Husson F, Josse J, Le S, Mazet J (2020) Multivariate exploratory data analysis and data mining. https://cran.r-project.org/web/packages/ FactoMineR/FactoMineR.pdf. Accessed 10 Mar 2021

Layuno MA (2007) El museo más allá de sus límites. Procesos de musealización en el marco urbano y territorial. Oppidum 3:133-164

Le Goff J (1998) Patrimoine et passions identitaires: Entretiens du Patrimoine, Théâtre national de Chaillot, Paris, 6, 7 et 8 janvier 1997. Paris, Fayard: Editions du Patrimoine

Lozano N (2018) El Concavenator aparece en "Jurassic World: el reino caído", la última película de Bayona. Las Noticias de Cuenca. https://www.lasnoticiasdecuenca.es/cultura/concavenator-apare ce-jurassic-world-reino-caido-ultima-pelicula-bayona- 35255 . Accessed 9 Mar 2021

Manucci F, Dal Sasso C, Auditore M, Romano M \& Maganuco S (2019) The 3D model of Scipionyx samniticus: an educational tool to learn the anatomy of a dinosaur. Paleodays 2019 - XIX Edizione delle Giornate di Paleontologia Benevento/Pietraroja (21)22-24(25) Maggio 2019

Martín-Abad H, Blanco-Moreno C, Barrios de Pedro S, MarugánLobón J, Poyato-Ariza FJ, Delvene G, Moratalla JJ, FregenalMartínez M, Vullo R, Cuesta E, Iniesto M, Barral A, Gomez B, Buscalioni AD (2017) The Exceptional Fossil Site of Las Hoyas (SPAIN) from an educational perspective. Geoheritage 10(3):463472. https://doi.org/10.1007/s12371-017-0270-z

MCCM (2019) Museo de Ciencias de Castilla-La Mancha - Programa General de Actividades 2019-2020. http://pagina.jccm.es/museo ciencias/TALLERES\%20WEB/PGAs2019-2020.pdf. Accessed 4 Feb 2020

Ministry of Education and Professional Training (2019) PISA 2018 Programa para la Evaluación Internacional de los Estudiantes. Informe español, Secretaría General Técnica, Madrid, España. https://sede.educacion.gob.es/publiventa/descarga.action?f_codigo_agc $=20372$. Accessed 17 Apr 2019

MUPA (2019) Museo de Paleontología de Castilla-La Mancha - Programa General de Actividades 2019-2020. https://mupaclm.es/ wp-content/uploads/2019/10/Presentaci\%C3\%B3n-PGA-19-20. pdf. Accessed 4 Feb 2020

Narváez I and Alfaro P (2019) De Gwangi a Concavenator. 50 años de paleontología en Cuenca. Cuenca, Spain. Museo de Paleontología de Castilla - La Mancha

Ortega F, Sanz JL, Barroso-Barcenilla F, Cambra-Moo O, Escaso F, García-Oliva M, Marcos-Fernández F (2008) El yacimiento de macrovertebrados fósiles del Cretácico Superior de Lo Hueco (Fuentes, Cuenca). Paleontol Nova Seminario Paleontol Zaragoza 8:119-131

Ortega F, Escaso F, Sanz JL (2010) A bizarre, humped Carcharodontosauria (Theropoda) from the Lower Cretaceous of Spain. Nature 467(7312):203-206 
Pardo D (2013) ¿Cuál es la diferencia entre un geek y un nerd? BBC MUNDO. Retrieved from: www.bbc.com/mundo/noticias/2013/ 06/130624_tecnologia_geek_nerd_definicion_diferencia_dp

Pascual-Barrio B (2006) Calidad, equidad e indicadores en el sistema educativo español. Pulso Rev Educ 29:43-58

Poyato-Ariza FJ and Buscalioni AD (2016) Las Hoyas: A Cretaceous Wetland. A multidisciplinary synthesis after 25 years of research on an exceptional fossil Lagerstätte from Spain. Germany: Friedrich Verlag

Rowe S, Nickels A (2011) Visitor motivations across three informal education institutions: an application of the identity-related visitor motivation model. Visitor Studies 14(2):162-175

Rudwick MJS (2008) The meaning of fossils: episodes in the history of palaeontology. University of Chicago Press

Salamanca JV, Delvene G, Menéndez S, Cortés ÁG, Martínez ED, Jiménez R (2018) El patrimonio paleontológico en España: una necesidad de consenso sobre su gestión y marco legal. PH: Boletín del Instituto Andaluz del Patrimonio Histórico 26(94):326-329

Sanz JL (2002) Starring T. rex!: dinosaur mythology and popular culture. Indiana University Press

Sanz JL, Ortega F, Shibata M, Cuesta E, Elvira Martín A, Escaso F, Fregenal MA, Marcos F, Martín H, de Miguel Chaves C, Mocho P, Narváez I, Páramo A, Pérez-García A (2015) Dinosaurios maravillosos de Cuenca. Cuenca: Diputación Provincial de Cuenca, 160
Scheersoi A (2015) Catching the visitor's interest. Natural History Dioramas. Dordrecht: Springer, 145-159

The Local (2019) Why Spain is failing in maths and science teaching. The Local Spain. https://www.thelocal.es/20191203/why-spainis-failing-in-maths-and-science-teaching/. Accessed 9 Mar 2021

UNESCO (2005) Vienna Memorandum on "World Heritage and Contemporary Architecture - Managing the Historic Urban Landscape". Vienna, Austria. https://whc.unesco.org/archive/2005/ whc05-15ga-inf7e.pdf. Accessed 6 May 2019

Valdecasas AG, Correas AM (2010) Science literacy and natural history museums. J Biosci 35(4):507-514

Vesci M, Conti E, Rossato C, Castellani P (2020) The mediating role of visitor satisfaction in the relationship between museum experience and word of mouth: evidence from Italy. TQM J

Wolny M (2011) Nicknames in Italian Popular Culture-the case of professional football players' nicknames in the media. Actes del XXIV Congrés Internacional d'ICOS sobre Ciències Onomàstiques

Yasunaga M (2014) Non-formal education as a means to meet learning needs of out-of-school children and adolescents. UNESCO Institute for Statistics (UIS) and the United Nations Children's Fund (UNICEF). http://ais.volumesquared.com/wp-content/uploa ds/2015/01/OOSC-2014-Non-formal-education-for-OOSC-final. pdf. Accessed 15 Jul 2019 